\title{
Islamic Social Reporting Disclosure and Determinant Factors: Empirical Evidence from Islamic Banks in
Indonesia
}

\author{
Sri Wahyuni \\ Universitas Muhammadiyah Purwokerto \\ yuni_7067@yahoo.co.id
}

\begin{abstract}
This research aims to measure Islamic Social Reporting Disclosure score and to test the factors that affected them. The determinant factors tested were Profitability, Company Size, Company Age, and Liquidity. The population in this research include Islamic banks in Indonesia in the period of 2013-2016. Purposive sampling was used and data were obtained from 36 observations in 9 Islamic Banks. The analytical technique used in this research was multiple linear regressions. The analysis results show that the awareness of Islamic banks to report their social responsibility is still low. Profitability has no positive effect on Islamic Social Reporting Disclosure. Bank size has a positive effect on Islamic Social Reporting Disclosure, while both Liquidity and Bank Age have a negative effect on Islamic Social Reporting Disclosure.
\end{abstract}

Keywords: profitability, company size, company age, liquidity, islamic banks.

\section{INTRODUCTION}

Sharia bank is a business institution which operates based on sharia values. Institutions which run their business based on sharia will referto the Holy Qur'an and Sunnah in interacting with the social environment and their stakeholders. Islamic Social Reporting is the answer and solution to the needs of the interested parties concerned with the company's financial statements [1] ISR becomes a very important thing for the reputation and performance of Islamic financial institutions, because by diclosuring the ISR, Islamic financial institutions that succeed in revealing their ISR value will be perceived as a reliable entity by the Muslim community in channeling their fund [2].

However, eventhough ISR disclosure is important, in Indonesia there is no uniform provision of items to be disclosed in the ISR. So far, companies in the world use disclosure standards indexed by Global Reporting Initiative (GRI) [3]. So, ISR items disclosed by each bank differ from bank to bank.

This is supported by the results of research conducted, among others [4] who tested 29 samples of Islamic banks in Islamic countries, which found that only
11 banks $(38 \%)$ disclosed their social responsibility according to AAOIFI standards (Accounting and Auditing Organization for Islamic Institutions). The results indicated that there are many Islamic banks that have not revealed their social responsibility as expected.

The results an Indonesian study conducted by Sofyani et al. [5] comparing the ISR index to measurethe social performance between Indonesian sharia banks and Malaysia sharia banks provide empirical evidence that all Islamic banks both in Indonesia and Malaysia are achieving excellent performances. Similar results are shown by the research of[6] who found that there are no Islamic banks, either in Indonesia or Malaysia that $100 \%$ implement their ISR's.

Consider the importance of Islamic social responsibility reporting for Islamic banks, this study measures the extent of social responsibility implementation of Islamic banks to the surrounding stakeholders, and tests the determinants affecting ISR, which include profitability, company size, company age, and liquidity.

\section{METHOD}

This quantitative research emphasizes on theories testing through research variables using numbers as a benchmark to test the hypothesis [7]. The population in this research includes all Sharia Commercial Bank in Indonesia in the period of 2013-2016. Sampling was taken using purposive sampling method. Data analysis was done by giving check mark on each item which revealed its social activity in sharia bank annual report. If there are items that are revealed, then it will get a score of " 1 " and if not, then it will get a score of "0". Checklist marks are based on content analysis contained in the annual report. In regard to ISR index components, there are 43 items divided into six categories, namely investment and finance, organizational governance, products and services, labor, social, and environment [8]. The items of Islamic Social Reporting consist of standard items of CSR specified by AAOIFI (Accounting and Auditing Organization for Islamic Institutions), later developed by researchers on CSR items that should be disclosed by an Islamic entity [8]. Islamic Social Reporting Disclosure (ISRD) is assessed by comparing the disclosure of Islamic Social Reporting, which has 
been done by a Sharia Bank with the maximum amount of ISRD to be disclosed by Sharia Commercial

The profitability ratio shows a company's ability to make a profit [9]. Profitability in this research is measured using Return on Assets (ROA) ratio. ROA as a proxy of profitability is measured by comparing profit before tax with total assets of the company.

Company size is the level of big or small company size identification. Larger companies do larger activities. The larger the company size, the more capital is invested so that large resources and funds within the company tend to have a wider demand for its corporate reporting information. Company size is measured using the total natural asset logarithm.
Bank.

The company age can be seen from how long the company is listed on the IDX. [10] [11] assumed that younger companies are predicted to spread more information than older companies with a view to reducing uncertainty of operating risks and to boost investor confidence in their positions [12].

Liquidity is a company's ability to fund its short-term liabilities. A measurement that can represent liquidity is by comparing the total current assets owned by the company with total short-term liabilities [13] [14].

Table1

RESULT

Index ISR Measurement Results During the Period Of 2013-2016

\begin{tabular}{|c|l|c|c|c|c|c|}
\hline \multirow{2}{*}{ Code } & \multicolumn{5}{c|}{ Bank } & \multicolumn{2}{c|}{ Year } & \multirow{2}{*}{ Average } \\
\cline { 2 - 6 } & & $\mathbf{2 0 1 3}$ & $\mathbf{2 0 1 4}$ & $\mathbf{2 0 1 5}$ & $\mathbf{2 0 1 6}$ & \\
\hline BMS & B.Mandiri Syariah & 62.79 & 60.46 & 60.46 & 60.46 & 61.04 \\
\hline BMI & B. Muammalat Indonesia & 60.46 & 60.46 & 60.46 & 60.46 & 60.46 \\
\hline BNIS & B.Negara Indonesia Syariah & 62.76 & 62.79 & 65.12 & 65.12 & 63.94 \\
\hline BCAS & B.Central Asia Syariah & 46.51 & 53.49 & 53.49 & 55.84 & 52.33 \\
\hline BUKOPIN & B.BUKOPIN & 48.84 & 53.49 & 55.81 & 60.46 & 54.65 \\
\hline BRIS & B.Rakyat Indonesia Syariah & 58.14 & 60.46 & 60.46 & 60.46 & 59.88 \\
\hline PANIN & B. PANIN Syariah & 48.84 & 58.14 & 58.14 & 62.79 & 56.98 \\
\hline MEGA & Bank Mega Syariah & 54.59 & 53.49 & 53.49 & 60.46 & 55.51 \\
\hline MAYBANK & Maybank Syariah & 46.51 & 46.51 & 48.84 & 48.84 & 47.67 \\
\hline
\end{tabular}

Source: content analysis, 2017

Table 2 indicates that the highest index score achieved by Bank Negara Indonesia Syariah is 63.94\%. Meanwhile, the lowest score occurred in Maybank Syariah with a score of $47.47 \%$.

Predicate of Sharia Banks Disclosure Score Based on ISRD Index

\begin{tabular}{|c|c|c|c|c|}
\hline \multirow{2}{*}{$\begin{array}{c}\text { Name of } \\
\text { Islamic Banks }\end{array}$} & \multicolumn{2}{|c|}{$\mathbf{2 0 1 3}$} & $\mathbf{2 0 1 4}$ & $\mathbf{2 0 1 5}$ \\
\cline { 2 - 5 } & \multicolumn{4}{|c|}{ Predicate } \\
\hline BSM & Less informative & Less informative & Less informative & Less informative \\
\hline BMI & Less informative & Less informative & Less informative & Less informative \\
\hline BNIS & Less informative & Less informative & Informative & Informative \\
\hline BCAS & Less informative & Less informative & Less informative & Less informative \\
\hline BUKOPIN & Not informative & Less informative & Less informative & Less informative \\
\hline BRIS & Less informative & Less informative & Less informative & Less informative \\
\hline PANIN & Not informative & Less Informative & Less informative & Less informative \\
\hline MEGA & Less informative & Less informative & Less informative & Less informative \\
\hline MAYBANK & Not informative & Not informative & Not informative & Not informative \\
\hline
\end{tabular}

Source: content analysis, 2017

Notes:

Predicate Classification:

Very Informative: $81 \%-100 \%$; Informative: $66-80 \%$; Less informative 51\%-65\%; Not informative: 0-50\%

Table 2 shows the ISRD predicate of Sharia Commercial Banks. From the nine samples of banks in the observation year of 2013-2016, banks that revealed its informative social responsibility is Bank BNI Syariah in 2015 and 2016. This result shown that the awareness of Islamic banks to report their social responsibility is still low.

Table 3 indicates, the profitability coefficient is 0.001 with a positive direction and the significance level is $0.301>0.05$. In the calculation $t_{\text {table }}=(n-k-1)$ notes that $t_{\text {table }}$ in this study is 1.697 , while $t_{\text {stat }}$ of $1.053<1.697$. This means that $\mathrm{H}_{0}$ is received and $\mathrm{H}_{\mathrm{a}}$ is rejected. The 
level of corporate profitability does not affect ISRD. Companies which have high profitability do not necessarily have more social activities because the companiesare more oriented to profit. The results of this study support research conducted by [9];[11]; [14] who found empirical evidence that profitability has no positive effect on ISR disclosure. However, to the findings of this study are contrary to the findings of [10]; [11]; [15]; and [16] who found that profitability has a positive effect on the extent of ISRD.

\section{Table 3}

Hypothesis Test Result

\begin{tabular}{|c|c|c|c|c|c|}
\hline Variable & $\begin{array}{l}\text { Hypothetical } \\
\text { Direction }\end{array}$ & $\beta$ & t-stat & $\mathrm{P}$ value & Decision \\
\hline Profitability & + & $\begin{array}{r}0.00 \\
1\end{array}$ & 1.053 & 0.301 & $\begin{array}{c}\text { Not } \\
\text { Supporte } \\
\text { d }\end{array}$ \\
\hline $\begin{array}{l}\text { Company } \\
\text { Size }\end{array}$ & + & $\begin{array}{r}0.03 \\
8\end{array}$ & 6.549 & 0.000 & $\begin{array}{c}\text { Supporte } \\
\text { d }\end{array}$ \\
\hline $\begin{array}{l}\text { Company } \\
\text { Age }\end{array}$ & + & - & -2.101 & 0.044 & $\begin{array}{c}\text { Not } \\
\text { Supporte } \\
\text { d }\end{array}$ \\
\hline Liquidity & + & -0.001 & -2.444 & 0.021 & $\begin{array}{c}\text { Not } \\
\text { Supporte } \\
\mathrm{d} \\
\end{array}$ \\
\hline
\end{tabular}

a.Dependent Variable : ISRD

The coefficient variable of company size is 0.038 with a positive direction and its significance level is $0.000 \leq 0.05$, whereas $t_{\text {stat }}$ is $6.549>1.697$. This means that $\mathrm{H}_{0}$ is rejected and $\mathrm{H}_{\mathrm{a}}$ is accepted. The results of this study support the theory of legitimacy that there is a social contract implicated between institutions and society. The bigger a company, the higher the level of corporate responsibility disclosure by Islamic banks [17]. The results of this study support research conducted by $[1,17,18]$ and $[14]$ which provide empirical evidence that company size positively affects ISRD. However, this study does not support the results of $[19,20]$ study which found that company size variable has no positive effect on ISRD.

The coefficient variable of company age is -0.002 with a negative direction and its significance level is $0.044<0.05$. Meanwhile, $\mathrm{t}_{\text {stat }}$ is $-2.101<1.697$. This means that $\mathrm{H}_{0}$ is accepted and $\mathrm{Ha}$ is accepted. The results of the study show the negative effect between company age and ISRD, which proves that younger companies will make it possible to disclose their Islamic social responsibility more broadly. It may be aimed at reducing risk uncertainty and increasing investor confidence, especially Muslim investors, towards their position. The results of this study support the study of [21] which provides empirical evidence that the company age has a positive effect on ISRD. However, this study does not support [11] study which provides empirical evidence that the company's age negatively affects ISRD.

The coefficient variable of liquidity is -0.001 with a negative direction and the significance level is $0.021<$ 0.05 . Meanwhile tstat is $-2.444<2.042$. This means that $\mathrm{HO}$ is rejected and $\mathrm{Ha}$ is accepted. These results indicate that Liquidity negatively affects ISR disclosure. From the results of the above analysis, it can be concluded that the higher the level of liquidity of Sharia Commercial Bank, the narrower the ISR disclosure is done. The results of this study support [21] and [22] studies which provide empirical evidence that liquidity negatively affects ISR disclosure. However, this study does not support the results of [20] which provides empirical evidence that liquidity positively affects ISRD.

\section{CONCLUSION}

From the calculation result of ISR Score, it can be concluded that the awareness of Islamic banks to report their social responsibility is still low. Profitability variable does not positively affect the disclosure of Islamic Social Reporting. The bank size variable has a positive effect on the disclosure of Islamic Social Reporting. The bank age and liquidityvariables negatively affect the disclosure of Islamic Social Reporting.

This study has some limitations that might affect the results that are: Index of disclosure of the ISR is directed to refer to Othman et al (2009). Further research is suggested to use the ISR index in addition to referring to Othman et al (2009). The goal is to find out how different the disclosure results are with other ISR indexes.

\section{REFERENCES}

[1] M. Hossain andH. Hammami,."Advance in Accounting, Incorporating Advance in International Voluntary Disclosure in the Annual Report of an Emerging Country: the case of Qatar. International journal of Cardiology. Vol 25, No.2, pp. 255-265, 2009.

[2] S. Lestari. "Pengaruh Tingkat Profitabilitas, Leverage, Likuiditas, Ukuran Perusahaan dan Umur Perusahaan terhadap Pengungkapan ISR pada Perbankan Syariah Tahun 2010-2014". Jurnal Ekonomi dan Bisnis, pp. 1-24,2016.

[3] Indrawaty and S.M.Wardayati. "Implementing Islamic Corporate Governance (ICG) and Islamic Social Reporting (ISR) in Islamic Financial Institusion".Procedia, Social and Behavior Science, Vol.219, pp. 338-343, 2016.

[4] B. Maali., P Casson \& C. Napier.."'Social Reporting by Islamic Banks".Ab. I 422 pp. 266289, 2006.

[5] Sofyani, Hafiez., I.Ulum., D.Syam., L.Wahyuni. 'Islamix Social Reporting Indeks Sebagai Model Pengukuran Kinerja Sosial Perbankan Syariah (Studi Komparasi Indonesia dan Malaysia)'. Jurnal Dinamika Akuntansi, Vol.4, No.1, pp, 3646, 2012.

[6] Wardayati, S.M dan S.A. Wulandari. "Comparasions and Differences of Level Islamic Social Reporting Disclosure Islamic Banking in Indonesia and Malaysia”. Proceeding. AICIS XV, Balikpapan,2014. 
[7] Indriantoro, Nur dan Bambang Supeno. "Metodologi Penelitian Bisnis" Edisi kedua. Yogyakarta: BPFE,2002.

[8] R.M.Haniffa. "Social Reporting Disclosure: An Islamic Perspective, Indonesian Management and Accounting Research" Vol.1. No.2, hal 128$146,2002$.

[9] F. Ramadhani, "Pengaruh Ukuran Perusahaan, Profitabilitas, Leverage, dan Ukuran Dewan Pengawas Syariah terhadap Pengungkapan ISR".JOM Fekom. Vol.3. No. 1, pp. 24872500.2016.

[10] R.M. Haniffa,\& T.E. Cooke. "The Impact of Culture and Governance on corporate social reporting.Journal of Accounting and Public Policy. Vol.24, pp..391-430, 2005.

[11] P.Lestari, "Determinants of Islamic Reporting In Syariah Bank: Case of Indonesia". International Journal of Business and management Invention. Vol 2. No. 10, hal 28-34, 2013.

[12] J. Jayanti. "Pengaruh Firm Size, Firm Age, Profitabilitas Terhadap Corporate Social Reporting". Diponegoro Accounting Journal.Vol. 9, pp. 120.2013.

[13] Elzahar, Hany \& Khaled, Hussainey. "Determinants of Narratife Risk Disclosures in UK Interim Report.The Journal of Risk Finance. Vol 12. No. 2, pp. 133-147,2012.

[14] Sunarsih, Uun dan Ferdiansyah. "Determinants of Islamic Social Reporting Disclosure".Al-Iqtishad. Vol.9 (1), pp 69-80, 2017.

[15] Taufiq, Marlina, Widianti dan Rafiqoh. "Pengaruh Islamic Governance Score, Leverage dan Profitabilitas terhadap Pengungkapan ISR".Jurnal Manajemen dan Bisnis Sriwijaya. Vol. 13. No. 2, pp. 177-198, 2015.
[16] L. Inuzula, "Pengaruh Size, Profitabilitas, dan Dewan Pengawas Syariah Terhadap Pengungkapan Islamic Social Reporting Pada Bank Umum Syariah di Indonesia". Jurnal Kebangsaan. Vol.6 no.11, pp. 32. 2017

[17] Jannah, Asrori, Awalya Ma'rifatul,"Pengaruh GCG, Size, Jenis Produk dan Kepemilikan Saham Publik Terhadap Pengungkapan ISR", Accounting Analysis Journal. Vol. 5. No. 1, pp. 130, 2016.

[18] Othman, Rohana., Azlan, Md Thani dan Erlane, K Ghani. "Determinants of Islamic Social Reporting Among Top Shariah-Aproved ompanies in Bursa Malaysia". Research Journal of International Studies Issue 12 Oktober 2009, pp 4-20, 2009.

[19] Verawaty, J.Darmawan dan K.Ayu, "Determinan Pengungkapan Islamic Social Reporting Pada Perusahaan Yang Terdaftar Di Jakarta Islamic Index" Jurnal Ekonomi. Vol. 4. No. 2, pp. 44-5, 2016.

[20] R. Rosiana,B. Arifin dan M.Hamdani."Pengaruh Ukuran Perusahaan, Profitabilitas, Leverage dan Islamic Governance Score Terhadap Pengungkapan Islamic Social Reporting” Jurnal Bisnis dan Manajemen. Vol. 5. No. 1, pp. 87-104, 2015.

[21] Yulianti., Leis, Suzanawwaty, Zuwesti, Eka Putri, Isnawati, Haribowo. "Determinant of The Corporate Environmental Disclosure: Study on Jakarta Islamic Index. Jurnal Ilmu Ekonomi Syariah. Vol. 8. No. 2, pp. 307-322, 2016.

[22] R.A. Sari. "Pengaruh Karakteristik Perusahaan Terhadap Corporate Social Responsibility Disclosure Pada Perusahaan Manufaktur Yang Terdaftar Dibursa Efek Indonesia".Jurnal Nominal. Vol. 1. No. 1, pp. 1-17, 2012. 